\title{
Innovation, Competitiveness and Prosperity: A Factor Analysis of Innovation Indicators in Spain
}

\author{
Antonio García-Sánchez, David Siles, María de Mar Vázquez-Méndez \\ Technical University of Cartagena, Cartagena, Spain
}

\begin{abstract}
Competitiveness is a wide concept applied to many fields, especially in economics. The study of tourism competitiveness has been focused on different factors that can enhance the prosperity of a destination. One of these factors is innovation. Innovation makes destination's enterprises more advanced and efficient, therefore more productive. Innovation is an enhancer of competitiveness and a generator of prosperity because innovation in every aspect (technology, knowledge, organization, and processes) will provide a better quality of life for the inhabitants of the destination. The incidence of innovation on these concepts is validated by a structural equation model. We measure innovation by a range of indicators and through a factor analysis; we get the most relevant indicators of innovation for the model developed in Spain.
\end{abstract}

Keywords: competitiveness, innovation, prosperity, tourism, factors, indicators

\section{Introduction}

Tourism competitiveness is defined as the characteristics of a destination that is allowed to attract visitors, to get revenue, to satisfy the tourists, and to give prosperity (Crouch \& Ritchie, 1999).

Many models present competitiveness as a multidimensional concept, there are several indicators that can help a destination to be more competitive, so the search of a suitable group of indicators for any destination is the key. The indicators are usually gathered in main categories, such as natural resources, location advantages, the cultural legacy, tourism policy, and other important concepts about the destination identity.

A competitive destination must offer quality of life, a place where the inhabitants are getting benefits from tourism. When the tourists come to the destination, they must feel that it is a good looking place to visit and a sustainable destination with plenty of resources that make richer the tourism experience. That is why competitiveness is focused on getting prosperity to the destination.

Among the variables that make the destination more competitive, there are variables related to innovation as telecommunication system, training programs for employees, or use of technology. The effectiveness of innovation as an indicator of competitiveness is confirmed in the tourism competitiveness models, the

Antonio García-Sánchez, Ph.D. in Economics, senior lecturer of Economy Department, Technical University of Cartagena, Cartagena, Spain.

David Siles, Ph.D. in Economics, associate researcher of Economy Department, Technical University of Cartagena, Cartagena, Spain.

María de Mar Vázquez-Méndez, Ph.D. in Economics, lecturer of Economy Department, Technical University of Cartagena, Cartagena, Spain.

Correspondence concerning this article should be addressed to Antonio García-Sánchez, Technical University of Cartagena, Real St. 4, Cartagena 30201, Spain. 
integrated model (Dwyer \& Kim, 2003) considered elements of innovation and technology in the determinants of competitiveness.

The way that innovation has become a relevant element in the business world has got implications at all levels. Innovative products and services are part of the destination resources and the inhabitants' way of life. People are in direct touch with new technologies, for trading or for leisure. These changes make us think about innovation as a concept that is having a direct incidence in the socio-economic prosperity of a destination.

The quality of life in a destination for both the inhabitants and the tourists will be better if innovation is developed in that destination. The innovative resources of a smart city can make tourism demand comfortable with the services available, like wifi, electronic translators, etc. as well as many advantages that can make the destination sustainable improving the efficiency of the energy resources for example.

It is clear that innovation can enhance the destination competitiveness, making the competitiveness indicators more effective. On the other half, innovation offers a range of advantages that have an incidence on the quality of life of the destination.

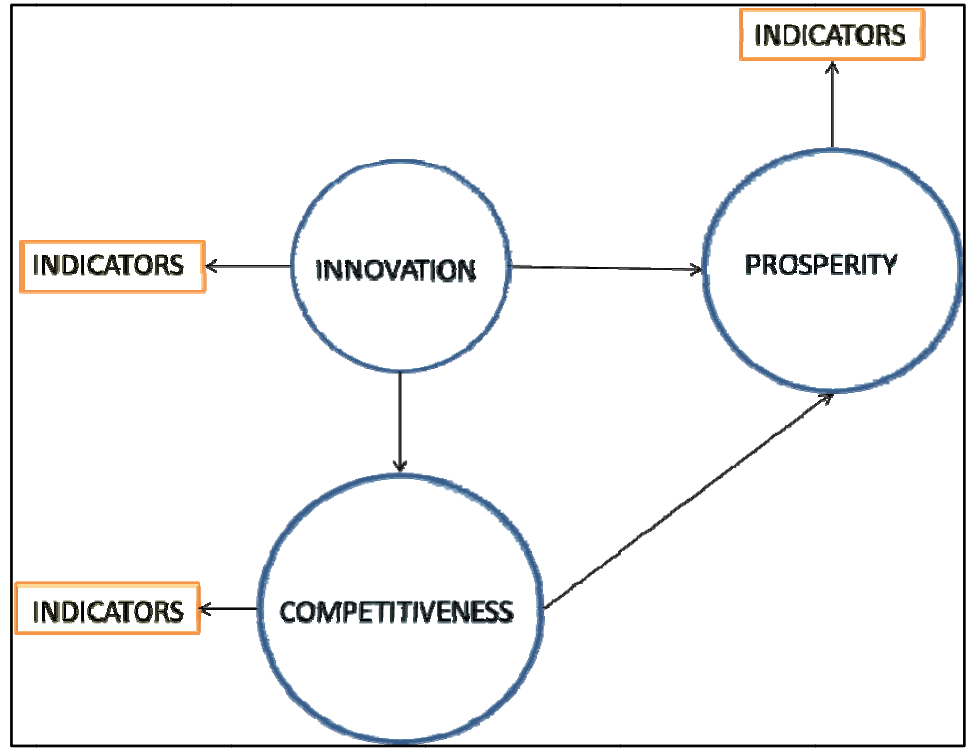

Figure 1. Theoretical model of competitiveness, innovation, and prosperity. Source: Own elaboration.

The model presented in Figure 1 has been tested with significative results. As García-Sánchez, Siles, and Vázquez-Méndez (2017) affirmed innovation as a construct has a positive and significative incidence on both competitiveness and prosperity constructs. Thus, the next logical step in the analysis is the research on the importance of the innovation's indicators in the model, this way the destination managers could focus on the proper indicators for enhancing destination competitiveness and improving prosperity.

The analysis of innovation became a necessary step to understand the evolution of tourism competitiveness. A range of indicators of innovation has been selected from the literature review, many articles and innovation guides show what kind of indicators should be representative of innovation in all of its ways.

A factor analysis of the indicators will display the variables in different categories classified depending on their relevance for the innovation in Spain.

The factor analysis will be carried out in the part of the methodology. Before that, a review of literature is made for the understanding of the theoretical framework of the concepts described, and the way they can 
establish their relationship. Finally, we can detail the conclusions obtained and confirm the theory proposed giving useful information to the destination managers.

\section{Literature Review}

Competitiveness is a concept that can be presented in many aspects of the society. Competitiveness can be defined, in a general way, as the ability to sell products getting benefits and resources (Scott \& Lodge, 1985). Tourism is a relevant sector in many countries that contributes to the economy in a significant way (World Travel and Tourism Council, 2017). During the last century, many countries focused their policies on tourism (World Economic Forum, 2017).

Tourism competitiveness is defined as the capacity of a destination for giving quality of life to its inhabitants (Crouch \& Ritchie, 1999). It is a complex concept composed of a range of indicators to get this purpose, and it can be different depending on the characteristics of every destination (Porter, Sachs, \& McArthur, 2001) but anyway, it must be oriented to get economic growth and prosperity.

The analysis of tourism competitiveness can improve the performance of the destinations in order to get prosperity (Dwyer \& Kim, 2003). Some of these indicators are more suitable than others depending on the characteristics of the different destinations. Indicators must contain both, demand and supply indicators, this way every aspect is considered (Kozak \& Rimmington, 1999). Therefore, a more detailed study would be necessary to determine the most suitable in every case.

Competitiveness is related to productivity. Newall (1991) commented that a competitive economy should be productive and sustainable for improving quality of life at destination. With productivity, costs can be reduced so prices will be lower, employment will rise and the level of life will be higher as Wysokinska (2003) affirmed.

Porter, Sachs, and Warner (2000) concluded that a competitive economy will lead to an increase in productivity and economic growth. Cadavid and Franco (2006) found a positive correlation between productivity and economic growth, so competitiveness is a key element in this relationship.

When talking about tourism destinations, Pulido and Sánchez-Rivero (2010) stated that competitiveness and economic growth have got a significative relation, more tourism competitiveness will give more tourism growth. Tourism capacity to generate employment and expenses will be able to increase wellness and economic development of the destination.

Finally, we can affirm that tourism destination competitiveness is related to socio-economic prosperity and quality of life (Dwyer, Mellor, Livaic, Edwards, \& Kim, 2004).

Innovation can be defined as the development of an idea and its implementation in the markets (Bulc, 2011). That idea should provide a new product or service, or an improvement of the old-one.

Innovation is a concept with high incidence in business. Companies are searching for innovation in their products in order to get new customers or to maintain their market share.

Innovation can be done in different aspects: innovation in products or services, in the production process, in organization management and marketing, and in the human resources (Meneses \& Teixeira, 2011).

Innovation is implemented as much in goods as in services sectors. The concept of product innovation is transferred to the services field where is applied to every aspect. One of the services' branches where innovation is an important element to boost competitiveness is tourism. 
In tourism, innovation has affected ICT (information and communication technologies) in a significant way. Innovation has introduced new concepts that have changed working and formation methodology (Sancho \& Maset, 1999). Tourism demand has evolved and it is more related with ICT, so it is necessary for the adaptation to demand in these terms.

Public organizations must encourage innovation with training politics about academic training and investment because with innovation, companies will get more profit with fewer costs (Rosenberg, 2006). In Spain, the more innovative hotels attract more tourists (Sundbo, Orfila-Sintes, \& Sorensen, 2007).

When innovation is generated, it will give a competitive advantage in order to get profits and a sustainable growth (Pavia, Stipanovic, \& Mrnjavac, 2011). The searching for innovation chases to increase competitiveness and, as a direct effect, productivity with better products (Sundbo et al., 2007). As Sancho and Maset (1999) also affirmed innovation has got a significative effect on productivity and this effect rises competitiveness.

The specialization in the product, as Porter (1990) said, spreads innovation. The more specialized provinces in tourism in Spain are the ones that contribute more, so they are more competitive, as Sancho (2008) pointed. Additionally, innovation is necessary to maintain the competitiveness position of the destinations. Buhalis (1998) indicated that destinations must use ICT and innovation methods in organization to keep their competitive position.

Innovation, as a matter of fact, helps the destination to increase competitiveness and to get more tourists. Victorino, Verma, Plaschaka, and Dev (2005) commented that innovation gets competitive advantages and the customer's preference, that is because destinations put efforts to attract and satisfy a very sophisticated demand that looks for new experiences (Hu, Horng, \& Sun, 2009). Innovation in the services available at the destination, transport services in special, has been very important because has made the feeling of distance between destinations shorter.

With innovation, production costs can be reduced, so it will increase productivity, innovation is an essential condition in economic development and a critical element in competitiveness (Freeman \& Soete, 1997). Puccio and Grana (2008) also affirmed that the innovation's capacity of a destination is a relevant parameter in the destination competitiveness.

Hjalager (2010) commented that innovation in the tourism industry has given benefits to managers and employees. Innovation can create employment (Maráková \& Medved'ová, 2010) and long-term economic growth (Rosenberg, 2003), so there will be a better quality of life in the destination.

Additionally, the model of growth of Porter et al. (2000) included innovation in order to get a high economic growth rate. Innovation in technology is an essential component in the model of growth (Romer, 1986), where innovation is an endogenous element in the long-run growth.

As Freeman and Soete (1997) commented innovation is a concept that can make the tourism destination more efficient and technologically advanced, leading to an improvement of the quality of life for the inhabitants and for the tourists. So, prosperity is linked to economical concepts, but also to quality of life concepts, such as having technological resources (like in a smart city), low pollution levels, or anything related to happiness.

Innovation must be made in a sustainable way. Hjalager (1997) commented that if a destination innovates but produces contamination in the process, the quality of life will be lower and the tourists will not go to that destination.

\section{Methodology}

For this study, data from different statistical sources have been extracted. Sources range from web 
statistics, such as official statistics institute in Spain or diverse official Ministery webs, to relevant surveys as employment surveys, technological surveys, or tourism surveys. Data year is 2015, the last year with the more updated data availability for the destinations selected. A cross sectional data from 2015 has been chosen, many variables do not vary through years, so this method is suitable for the results we are looking for.

Spain is a recognized destination in tourism terms according to the Travel and Tourism Competitiveness Report (World Economic Forum, 2017). A deep study of tourism and the innovation variables that can enhance tourism competitiveness and prosperity will report benefits for tourists and inhabitants at the destination. The number of observations is based on the number of provinces, Spain has got 52 provinces.

The innovation indicator's research has been made following different articles or handbooks about innovation and its development in the destinations. Indicators like R\&D (research and development) expenses, universities, investigation centers, equipment, and knowledge acquisition, innovation policies, etc. are described in the Oslo's Manual (OECD, 2005). Industrial development, human resources' training, or new software development are also cited in the Frascatti's Manual (OECD, 2002). Other indicators related to innovation are detailed in articles, such as "Innovation in Spain" (FECYT, 2014), the "European Innovation Scoreboard” (European Commission, 2016), Malinosky and Perry (2011), Adams and Jaffe (1996), Klette (1994), Rogers (1998), Dwyer and Kim (2003), Puccio and Grana (2008), Álvarez et al (2008), or the included in the National Research Council (1997).

A dataset of 28 innovation indicators has been disposed for this study. All the data have been transformed to logarithms, this way we can eliminate the effect of the different measures from the data and take into account only the difference between observations. Additionally, we can understand the results from the model in an easier way.

\section{Factor Analysis}

Principal component analysis (PCA) (Sharma, 1998) responds to our data exploration needs. Data reduction methods have been used before in the field of tourism destination competitiveness (Dwyer et al., 2004). Using this method we also can discover an underlying disposal of the variables. A method based on PCA was applied, and then, we used the varimax rotation in order to get better results of saturation of the variables in the factors. The extraction method used was parallel analysis, the best extraction method according to Horn (1965) and it coincides with the eigenvalue mayor than one's method in this case.

This method can be seen as a dimensional reduction technique that accounts for the maximum variance possible of the total variance with any new variable. Data are logarithm transformed, in this way the problems because of the different measures of the variables are eliminated. Then, we standardize the values because we do not want the relative variance among the original variables to affect the weights. If we did not do this, the variables with greater variance would be given a greater weight. By doing this, no variable is more significant than any other and will not be assigned a higher weight because we do not know whether it deserves this. Another reason for standardising the data is that it makes it easier to interpret the results. For example, the Barlett test can be used with standardised data.

In the principal component case, initial communalities are 1 , because this method supposes that $100 \%$ of the observed variance can be explained. When considering the variables' load in each factor, in the case of variables load in equal parts in its factor or do not load in any factor, we will rotate the component matrix with an orthogonal method which defines a new axis orthogonal to the original ones with the goal of maximizing 
variances of squared loadings. This way, components will load to 1 or 0 (varimax technique).

The extracted variables must explain enough variance to be retained, all the communalities are high enough, around 0.7, except for one variable that is around 0.5 but is acceptable, Barlett Sfericity test is significative, so we can apply the PCA. KMO test is near to $1(0.845)$, so it is a very good value.

We obtain three factors that explain the 80 (24\%) of the variance. Some variables do not have the suitable loading in any factor, so we have to quit these variables that did not saturate in any factor, econometric theories recommend putting aside the variables that do not contribute to the model because other variables in the model gather their effects; the model must be as parsimonious as possible so it is recommended to erase the variables with loadings lower than 0.25 . We perform the factor analysis again getting three factors, but this time all the variables have got the appropriate loading, so in the end, we get 18 variables, the indicators and their definition are detailed in Table 2 of the appendix. All loadings are higher than 0.6. Factors are renamed for easier interpretation.

Table 1

Factors and Variables From ACP

\begin{tabular}{ll}
\hline Factor 1: Innovation research & Factor loadings \\
\hline Investigation centers & 0.790 \\
Technology centers & 0.714 \\
Industrial design patents & 0.781 \\
Equipment goods exports & 0.804 \\
Equipment goods export companies & 0.939 \\
Technology imports & 0.794 \\
Technological companies & 0.835 \\
New brands & 0.927 \\
Industrial and technology employment & 0.929 \\
Technology parks & 0.768 \\
Technology patents & 0.943 \\
Smart cities & 0.601 \\
Doctoral dissertations & 0.807 \\
\hline Factor 2: ICT innovation & \\
\hline Internet access index & 0.941 \\
Smart phone index & 0.729 \\
Computer index & 0.860 \\
\hline Factor 3: Tourism innovation & \\
\hline Tourists using internet index & 0.872 \\
Tourism information searching index & 0.872 \\
\hline Source Own elaboran & \\
\hline
\end{tabular}

Source: Own elaboration.

Factor 1: Innovation research (explained variance 59.06\%). As it is common in factor analysis, the first factor comprises a large number of variables. This factor show the importancy of the research in innovation represented by variables, such as innovation and technological centers, patents and brands, export and import of technology goods, or research at universities. The most important indicators for this factor are the new patents and brands, which is a sign of innovation development in any society, and the variables related to innovation employment and exports of equipment goods, variables that helps to develop the destinations economically. 
Factor 2: ICT innovation (explained variance 11.18\%). It represents the necessity of the ICT technologies in our society. The factor is composed of indexes such as having smartphones and personal computers or internet access. Having internet access is the variable that contributes more to the factor; it is a very common and useful tool nowadays for everyone.

Factor 3: Tourism innovation (explained variance 10\%). This factor is composed of variables related to tourism innovation that tourists use, indicators like use of internet by tourists or if they search for tourism information at the internet. The two indicators have the same importance in the factor.

Table 2

Used Variables, Description and Source

\begin{tabular}{ll}
\hline Brands: Number of registered brands & www.oepm.es \\
\hline Computer: computer owned index & www.ine.es \\
Equipment exp. comp.: number of companies that are exporting equipment goods & www.icex.es \\
Import ind. \& tech. goods: value in euros of imports of industrial and technology goods & www.icex.es \\
Industrial design: number of new industrial designs & www.oepm.es \\
Industrial employment: number of workers in the industrial sector & www.seg-social.es \\
Info research Egatur: index of tourists that search information in the Internet & www.tourspain.es \\
Internet access index: index of internet access & www.ine.es \\
Patents: number of new patents & www.oepm.es \\
Research centers: number of research centers & www.csic.es \\
Smart city: number of smart cities & www.redciudadesinteligentes.es \\
Smart phone: smart phone owned index & www.ine.es \\
Tech. centers: number of technology centres & www.fecyt.es \\
Tech. parks: number of technology and science complex & www.fecyt.es \\
Technological companies: index of ICT companies & www.rmc.es \\
Thesis: number of doctoral thesis & www.educacion.gob.es \\
Total export equipment: value of exports of equipment goods & www.icex.es \\
Web access by tourists: index of use of internet by tourists & www.ine.es
\end{tabular}

\section{Conclusion and Implications}

Tourism competitiveness is a relevant concept for the destinations that want to increase their prosperity. The study of the innovation indicators suitable for the destinations analyzed should lead to a better management of the destination through a model that can confirm the importance of these indicators. This article has generated some relevant implications for destination managers.

As we noted in the introduction, tourism is an important resource for the Spanish provinces. Understanding the importance of tourism in the world economy and the value that tourism can add to a region's competitiveness allows managers to consider the steps they can take to ensure advantages to improve their region's competitiveness.

We agree with the literature that innovation must be measured through indicators. Logically, it is hard to account for every indicator that defines innovation in a given destination. By taking into account data limitations, we have selected the most suitable indicators.

This model represents the concepts we wanted to show. The results are robust and the tests realized have verified the suitability of the model. 
The relationship between innovation and competitiveness and the effect of innovation on prosperity are proved with significant results. The suitability of innovation as a concept that can increase prosperity and competitiveness for the destinations is a fact that needs to be analysed separately in order to check. Innovation is introduced with the aim of lift the quality of life of the inhabitants and the tourists that are visiting the destination, making the tourist experience more satisfying.

We have provided the destination managers with a scale to measure innovation at the tourism destinations. Innovation measures must be based on three factors, innovation about R\&D, technology for people making smart-people, and technology for tourism. The search of indicators related to these three factors is a key for innovating and generate competitiveness and prosperity at the destinations.

Innovation in Spain can be resumed into three factors, according with our model. The factors, in order of relevance into the model, are referred to the innovation carried out into the field of the research, variables such as technological centers, trading of technology, and knowledge research are very important for the first factor. Factor 2's variables show us the importance of being connected and having devices to do it, innovation of devices make people to be updated and connected. Finally, innovation in tourism that allows tourists to develop their tourism experiences, the third factor represents how new technologies give tourists the opportunity to arrange their travel and look for information about their travel destinations.

This work has used 2015 data. Limitations in the data could have affected the final incidence of the variables. The result is satisfactory, but there is room for additional research like the innovation indicators' incidence on the prosperity of the destinations with other methods as a linear regression in the same year or with time series. A more complete model with a higher number of observations would be desirable, too.

\section{References}

Adams, J., \& Jaffe, A. (1996). Bounding the effects of R\&D: An investigation using matched establishment-firm data. Rand Journal of Economics, 27(4), 700-721.

Álvarez, S. A., Rego, V. G., Leira, L. J., Gomis, R. A., Caramés, V. R., \& Andrade, S. M. J. (2008). Innovación turística: Perspectivas teóricas y objetos de estudio. Revista de Ocio y Turismo, 1, 19-50.

Buhalis, D. (1998). Strategic use of information technology in the tourism industry. Tourism Management, 19(5), $409-421$.

Bulc, V. (2011). Innovation ecosystem and tourism. Academia Turística, 4(1), 27-34.

Cadavid, H. J. V., \& Franco, G. H. (2006). Factores determinantes de la relación entre el crecimiento económico, la equidad y la competitividad. Ecos de Economía, 10(23), 107-153.

Crouch, G. I., \& Ritchie, J. R. B. (1999). Tourism, competitiveness, and societal prosperity. Journal of Business Research, 44(3), 137-152.

Dwyer, L., \& Kim, C. (2003). Destination competitiveness: Determinants and indicators. Current Issues in Tourism, 6(5), 369-414.

Dwyer, L., Mellor, R., Livaic, Z., Edwards, D., \& Kim, C. (2004). Attributes of destination competitiveness: A factor analysis. Tourism Analysis, 9(1-2), 91-101.

European Commission. (2016). European innovation scoreboard 2016. Belgium: European Union.

Fundación Española para la Ciencia y Tecnología (FECYT). (2014). La innovación en españa según el cuadro de indicadores de la unión por la innovación. Spain: Fundación Española para la Ciencia y la Tecnología.

Freeman C., \& Soete, L. (1997). The economics of industrial innovation. Cambridge, USA: Mit Press.

García-Sánchez A., Siles D., \& Vázquez-Méndez, M. M. (2017). Competitiveness, innovation, and prosperity: A necessary association. The 9th World Conference for Graduate Research in Tourism, Hospitality, and Leisure, 6th-11th of June, Cartagena, Spain.

Hjalager, A. M. (1997). Innovation patterns in sustainable tourism. Tourism Management, 18(1), 35-41.

Hjalager, A. M. (2010). A review of innovation research in tourism. Tourism Management, 31(1), 1-12.

Horn, J. (1965). A rationale and test for the number of factors in factor analysis. Psichometrica, 30(2), 179-185. 
Hu, M. M., Horng, J., \& Sun, Y. C. (2009). Hospitality teams: Knowledge sharing and service innovation performance. Tourism Management, 30(1), 41-50.

Klette, J. (1994). R \& D, Scope economies and company structure: A “not-so-fixed effect” model of plant performance. Discussion Papers, No. 120. Statistics Norway, Research Department.

Kozak, M., \& Rimmington, M. (1999). Measuring tourist destination competitiveness: Conceptual considerations and empirical findings. International Journal of Hospitality Management, 18(3), 273-283.

Malinoski, M., \& Perry, G. S. (2011). How do I measure “innovation”? March 24, 2017 Retrieved from http://www.balancedscorecard.org/portals/0/pdf/Howtomeasureinnovation.pdf

Maráková,V., \& Medved’ová, M. (2010). Innovation in tourism destinations. Forum Scientiae Oeconomia, 4(1), 33-43.

Meneses, O., \& Teixeira, A. (2011). The innovative behaviour of tourism firms. Economics and Management Research Projects: An International Journal, 1(1), 25-35.

National Research Council. (1997). Industrial research and innovation indicators: Report of a workshop. Washington, DC: The National Academies Press. doi: 10.17226/5976

Newall, J. E. (1991). The challenge of competitiveness. Business Council of National Issues. Winnipeg, Canada.

Organization for Economic Co-operation and Development (OECD). (2002). Frascati manual, proposed standard practice for surveys research and experimental development. Paris: OECD Publications.

OECD. (2005). Oslo manual: Guidelines for collecting and interpreting innovation data (3rd ed.). Paris: OECD Publications.

Pavia, N., Stipanovic, C., \& Mrnjavac, E. (2011). Innovation of business culture with the aim of developing Croatian tourism-case study of valamar hotels and resorts. Academia Turística, 4(1), 95-102.

Porter, M. E. (1990). The competitive advantage of nations. New York, N.Y.: Free Press.

Porter, M. E., Sachs, J. D., \& Warner, A. M. (2000). Executive summary: Current competitiveness and growth competitiveness. In The Global Competitiveness Report 2000: The World Economic Forum (pp. 14-17). Oxford: Oxford University Press.

Porter, M. E., Sachs, J. D., \& McArthur, J. W. (2001). Executive summary: Competitiveness and stages of economic development. In The Global Competitiveness Report 2001-2002: The World Economic Forum (pp. 16-25). Oxford: Oxford University Press.

Puccio, H., \& Grana, N. (2008). La innovación como requisito para la competitividad turística. Gestión Turística, (10), 59-76.

Pulido, F. J. I., \& Sánchez-Rivero, M. (2010). Competitividad versus crecimiento en destinos turísticos: Un análisis mediante técnicas multivariantes. Cuadernos de Economía, 33(91), 159-181.

Rogers, M. (1998). The definition and measurement of innovation. Melbourne Institute Working Paper 10/98. ISSN: 1328-4991; ISBN: 0-7325-0973-4

Romer, P. M. (1986). Increasing returns and long-run growth. The Journal of Political Economy, 94(5), 1002-1037.

Rosenberg, N. (2003). Innovation and economic growth. OECD Conference of Innovation and Growth in Tourism. Lugano, 18-19 September, Switzerland.

Rosenberg, N. (2006). Innovation and economic growth. Paris: OECD Publications.

Sancho, P. A., \& Maset L. A., (1999). Sector turístico e innovación: Un análisis a través de patentes. I Congreso Nacional Turismo y Tecnologías de la Información y las Comunicaciones: Nuevas Tecnologías y Calidad (pp. 249-261). Retrieved from https://www.uv.es/sancho/nt2.pdf

Sancho, P. A. (2008). Innovación tecnológica, Competitividad y productividad: Una aproximación al sector hostelería y restauración de la comunidad valenciana. Revista de Ocio y Turismo, 1, 153-164.

Scott, B. R., \& Lodge, G. C. (1985). U.S. competitiveness in the world economy. Boston, USA: Harvard Business School Press.

Sharma, S. (1998). Applied multivariate techniques. New York, US: Wiley.

Sundbo, J., Orfila-Sintes, F., \& Sorensen, F. (2007). The innovative behaviour of tourism firms-comparative studies of Denmark and Spain. Research Policy, 36(1), 88-106.

Victorino, L., Verma, R., Plaschaka, F., \& Dev, C. (2005). Service innovation and customer choices in the hospitality industry. Managing Service Quality, 15(6), 555-576.

World Economic Forum. (2017). The Travel \& Tourism Competitiveness Report 2017. May 8, 2017 Retrieved from https://www.weforum.org/reports/the-travel-tourism-competitiveness-report-2017

World Travel and Tourism Council. (2017). Economic Impact 2017. May 8, 2017 Retrieved from https://www.wttc.org/research/economic-research/economic-impact-analysis/

Wysokinska, Z. (2003). Competitiveness and its relationships with productivity and sustainable development. Fibre and Textiles in Eastern Europe, 11(3), 11-14. 